\title{
Interleukin-2-Inducible T-Cell Kinase Deficiency Impairs Early Pulmonary Protection Against Mycobacterium tuberculosis Infection
}

\author{
Lu Huang ${ }^{1}$, Kaixiong Ye ${ }^{2,3}$, Michael C. McGee ${ }^{4}$, Natalie F. Nidetz ${ }^{4}$, Jessica P. Elmore ${ }^{1}$, \\ Candice B. Limper ${ }^{1}$, Teresa L. Southard ${ }^{5}$, David G. Russell ${ }^{1}$, Avery August ${ }^{1 *}$ and \\ Weishan Huang ${ }^{1,4 *}$ \\ ${ }^{1}$ Department of Microbiology and Immunology, College of Veterinary Medicine, Cornell University, Ithaca, NY, United States, \\ ${ }^{2}$ Department of Genetics, University of Georgia, Athens, GA, United States, ${ }^{3}$ Institute of Bioinformatics, University of \\ Georgia, Athens, GA, United States, ${ }^{4}$ Department of Pathobiological Sciences, School of Veterinary Medicine, Louisiana \\ State University, Baton Rouge, LA, United States, ${ }^{5}$ Department of Biomedical Sciences, College of Veterinary Medicine, \\ Cornell University, Ithaca, NY, United States
}

\section{OPEN ACCESS}

Edited by: Igor Kramnik,

Boston University, United States

Reviewed by:

Chinnaswamy Jagannath, University of Texas Health Science Center at Houston, United States António Gil Castro,

University of Minho, Portugal

*Correspondence: Avery August averyaugust@cornell.edu Weishan Huang huang1@/su.edu

\footnotetext{
Specialty section:

This article was submitted to $T$ Cell Biology,

a section of the journal

Frontiers in Immunology
}

Received: 30 October 2019 Accepted: 19 December 2019 Published: 24 January 2020

Citation:

Huang L, Ye K, McGee MC, Nidetz NF Elmore JP, Limper CB, Southard TL, Russell DG, August $A$ and Huang $W$ (2020) Interleukin-2-Inducible T-Cell Kinase Deficiency Impairs Early Pulmonary Protection Against Mycobacterium tuberculosis Infection.

Front. Immunol. 10:3103. doi: 10.3389/fimmu.2019.03103
Interleukin-2 (IL-2) inducible T-cell kinase (ITK) is a non-receptor tyrosine kinase highly expressed in T-cell lineages and regulates multiple aspects of T-cell development and function, mainly through its function downstream of the T-cell receptor. Itk deficiency can lead to CD4 lymphopenia and Epstein-Bar virus (EBV)-associated lymphoproliferation and recurrent pulmonary infections in humans. However, the role of the ITK signaling pathway in pulmonary responses in active tuberculosis due to Mtb infection is not known. We show here that human lungs with active tuberculosis exhibit altered T-cell receptor/ITK signaling and that Itk deficiency impaired early protection against $M$ tb in mice, accompanied by defective development of IL-17A-producing $\gamma \delta T$ cells in the lungs. These findings have important implications of human genetics associated with susceptibility to $M$ tb due to altered immune responses and molecular signals modulating host immunity that controls Mtb activity. Enhancing ITK signaling pathways may be an alternative strategy to target $M$ tb infection, especially in cases with highly virulent strains in which IL-17A plays an essential protective role.

Keywords: active tuberculosis, transcriptomic analysis, non-receptor tyrosine kinase, IL-17A, IFN- $\gamma, \gamma \delta$ T cells

\section{INTRODUCTION}

Mycobacterium tuberculosis $(M t b)$ is the causative agent of what remains one of the most insidious and invasive human infections, responsible for millions of cases of active lung diseases and deaths per year in the world [WHO Global Tuberculosis Report, (1) and O'Garra et al. (2)]. The immune responses by macrophages, neutrophils, and T-cell populations contribute to protective immunity controlling $M t b$ expansion in the host and transmission to others $(2,3)$. Genetic and environmental factors of the host associated with primary and acquired immunodeficiency can lead to an increased risk of developing active tuberculosis that presents severe pulmonary illness in the clinic $(2,4)$. Our knowledge of the molecular pathways of innate and adaptive immune effector functions remains incomplete, and a better understanding of potential host factors underlying the pulmonary complications could lead to the development of more innovative therapeutic strategies. 
Interleukin-2 (IL-2)-inducible T-cell kinase (ITK) is a nonreceptor tyrosine kinase highly expressed in $\mathrm{T}$ cells. ITK functions downstream of the T-cell receptor (TCR) and regulates multiple aspects of T-cell development and function (5). ITK deficiency in humans is associated with primary immunodeficiency, progressive natural killer $\mathrm{T}$ (NKT) and $\mathrm{CD}^{+}{ }^{+}$T-cell lymphopenia, elevated susceptibility to EpsteinBar virus (EBV), and EBV-driven lymphoproliferative diseases, in which frequent pulmonary involvement has emerged as a clinical hallmark (6-13). Recurrent progressive pulmonary infection, airway obstruction, and respiratory failure in ITKdeficient patients pose significant threats that can eventually result in deaths of the patients at their early ages (12). Human $\mathrm{T}$ cells from patients with ITK deficiency exhibit impaired responses to TCR activation, with reduced generation of Th17 cells and production of the associated cytokines IL-17A, IL22, and granulocyte-macrophage colony-stimulating factor (14). A murine model of $I t k$ deficiency reveals a similar NKT and T-cell lymphopenia as observed in human patients with ITK deficiency. Mice lacking $I t k$ have a marked reduction in NKT cells (15-18). Despite relatively normal number (trending the lower range) of $\mathrm{CD}^{+} \alpha \beta \mathrm{T}$ cells, $I t k^{-/-}$mice exhibited $\mathrm{CD} 4^{+}$ $\alpha \beta$ T-cell lymphopenia, with reduced proportion of naive and increased memory $\alpha \beta \mathrm{T}$ cells (19-31). In the absence of Itk, mouse $\mathrm{CD}^{+} \mathrm{T}$ cells are impaired in Th2 (producing IL4/5/13) (32-38), Th9 (producing IL-9) (39), Th17 (producing IL-17) (35, 40-42), and Tr1 (producing IL-10) cell responses (43), while they are enhanced in Th1 (producing IFN- $\gamma$ ) cell response $(32,34,38,44,45)$. Analysis of $I t k^{-/-}$mice also reveals altered $\gamma \delta$ T-cell development (46-49); however, the presence and function of $\gamma \delta \mathrm{T}$ cells has not been evaluated in ITKdeficient humans.

Epidemiological analysis of single-nucleotide polymorphism has also revealed a connection between greater ITK promoter activity and higher risk of asthmatic incidence in humans, which might be associated with the function of ITK in promoting T-cell activation (50). In murine models of allergic asthma, the expression of ITK is critical for the activation and development of Th2 and Th17 cells and the associated airway and tracheal inflammation (40, 51). Interestingly, a genome-wide association study of susceptibility to Mycobacterium avium subspecies paratuberculosis in Holstein cattle identified chromosomal regions that included the ITK gene (52). However, the role of ITK signaling pathway in pulmonary responses in active tuberculosis due to $M t b$ infection is unknown.

Here, we show that the TCR/ITK signaling pathway is enriched in human lungs with active tuberculosis and that Itk deficiency impaired early protection against $M t b$ in mice, accompanied by defective development of IL-17A-producing $\gamma \delta$ $\mathrm{T}$ cells in the lungs. Furthermore, ITK appears to regulate the dynamics of lung myeloid cells, which may further contribute to immune control of $M t b$ at the early stage of infection.

Abbreviations: CFU, colony-forming unit; GSEA, gene set enrichment analysis; ITK, IL-2-inducible T-cell kinase; Mtb, Mycobacterium tuberculosis; NK, natural killer; TCR, T-cell receptor; Treg cells, Foxp3-expressing regulatory T cells.

\section{MATERIALS AND METHODS}

\section{Mice}

All mice were on the C57BL/6 background. Both female and male mice at the age of 6-12 weeks were used. All experiments were approved by the Office of Research Protections Institutional Animal Care and Use Committee at Cornell University.

\section{Microarray and Data Analyses}

Microarray data from lung normal tissue and caseous granulomas from active tuberculosis (TB) patient was generated as previously described $(53,54)$. Microarray data is available in the Gene Expression Omnibus under accession number GSE20050. In brief, tissues were fixed, and areas of interest were dissected using laser capture microdissection on the Leica AS LMD system (Leica, Buffalo Grove, IL). Total RNA was isolated and used on the GeneChip Human X3P Array (Affymetrix, Santa Clare, CA) following the manufacturer's instruction. Data analysis was performed in $\mathrm{R}$ (version 3.5.3) and Bioconductor (version 3.8). Probe intensities were $\log _{2}$ transformed and median centered. Differentially expressed genes were identified with limma (version 3.38.3) (55). In the case of multiple probes mapped to a gene, the probe with the maximum fold change was selected to represent the gene. Gene set enrichment analyses (GSEA) to determine over- and underrepresented gene sets were performed using the Kyoto Encyclopedia of Genes and Genomes pathway database as reference in gage (version 2.32.1) (56). All pathways that exhibited an up- or downregulated trend in caseum samples compared to normal tissues are summarized in the Supplementary Material (Supplementary Table 1). Enrichment score and core genes that drive the score are determined using the GSEA platform developed by the Broad Institute (57). Visualization of TCR signaling pathway with differential gene expression was performed in pathview (version 1.22.3) (Supplementary Figure 1) (58).

\section{Mtb Infection and Colony-Forming Unit Counts}

Mice were inoculated intranasally with $\sim 1,000$ CFUs of Erdman $M t b$ constitutively expressing mCherry (mCherry-Mtb) (59) in $25 \mu l$ of phosphate-buffered saline (PBS) containing $0.05 \%$ Tween-80. Mice were euthanized after 2 and 4 weeks of infection. The left lung lobe and the accessory lobe of the right lung were removed and homogenized in PBS containing 0.05\% Tween-80. Bacterial loads were determined by plating serial dilutions of the homogenates on $7 \mathrm{H} 10$ agar plates.

\section{Histology and Pathogenic Scoring}

Lung samples were fixed in $4 \%$ paraformaldehyde overnight, followed by hematoxylin and eosin (H\&E) staining. Histological images were analyzed using DP2-BSW software (Olympus, Waltham, MA) to quantify the percentage of affected tissue area and score the severity of pathology (60). 


\section{Isolation of Lung Cells}

Mice were euthanized at the indicated time points, and lungs were aseptically removed. To obtain a singlecell suspension, lungs were minced and digested in 5\% fetal bovine serum/PBS solution containing $250 \mathrm{U} / \mathrm{ml}$ collagenase IV (Worthington, Lakewood, NJ) and 20 $\mathrm{U} / \mathrm{ml}$ DNase (Roche, Indianapolis, IN) for $30 \mathrm{~min}$ at $37^{\circ} \mathrm{C}$. Lung digestions were then passed through a 70 $\mu \mathrm{m}$ cell strainer, and red blood cells were lysed with ammonium-chloride-potassium buffer.

\section{Fluorescent Mouse Antibodies}

Fluorescent antibodies are listed in the format of "Fluorophoretarget (clone)": eFluor 450-CD4 (GK1.5), Phycoerythrin (PE)-Foxp3 (FJK-16s), PE-eFluor 610-NK1.1 (PK136), allophycocyanin (APC)-IL-17A (eBio17B7), APC-CD11c (N418), PerCP-eFluor 710-CD49b (DX5), PE-Cy7-NK1.1 (PK136), PE-Cy7-IFN- $\gamma$ (XMG1.2), and APC-eFluor 780MHCII (M5/114.15.2) were from eBioscience (San Diego, CA). CD16/32 (93; i.e., Fc block), Brilliant Violet 421-CD64 (X545/7.1), Alexa Fluor 488-TCR $\gamma \delta$ (GL3), and APC-Cy7-TCR $\beta$ (H57-597) were from BioLegend (San Diego, CA). FITCLy6G (1A8), PE-Siglec-F (E50-2440), PE-TNF- $\alpha$ (MP6-XT22),
PE-CF594 CD8 $\alpha$ (53-6.7), Alexa Fluor 700-Ki67 (B56), PerCPCy5.5-CD8 $\alpha$ (53-6.7), and PerCP-Cy5.5-CD11b (M1/70) were from BD Biosciences (San Jose, CA).

\section{T-Cell Stimulation}

To activate bulk T cells, cells were stimulated with phorbol 12 myristate 13 -acetate (PMA) (50 ng/ml, Sigma) and Ionomycin $\left(0.5 \mu \mathrm{M}\right.$, Sigma); to activate $M t b$-specific $\mathrm{CD} 4^{+} \mathrm{T}$ cells, cells were stimulated with ESAT- $6_{4-17}$ peptide (MHCII-restricted presentation; synthesized by GenScript, purity $>95 \% ; 5 \mu \mathrm{g} / \mathrm{ml}$ ); to activate $M t b$-specific CD ${ }^{+} \mathrm{T}$ cells, cells were stimulated with TB10.4 $4-11$ peptide (MHCI-restricted presentation; synthesized by GenScript, purity $>95 \% ; 5 \mu \mathrm{g} / \mathrm{ml}$ ). All stimulations were done in full RPMI-1640 media in the presence of Brefeldin A $(5 \mu \mathrm{g} / \mathrm{ml}$, Sigma) and Monensin ( $2 \mu \mathrm{M}$, Sigma), at $37^{\circ} \mathrm{C}$ for $5 \mathrm{~h}$.

\section{Flow Cytometry}

Surface protein staining was done with antibodies for surface markers in PBS, in the presence of Fc Block (BioLegend) and fixable viability dye (Tonbo Biosciences). To determine cytokine production, cells were stimulated as indicated, followed by surface staining, then were fixed with $4 \%$ paraformaldehyde (Electron Microscopy Sciences, Hatfield, PA), and permeabilized and stained with antibodies in PBS containing $0.3 \%$ saponin

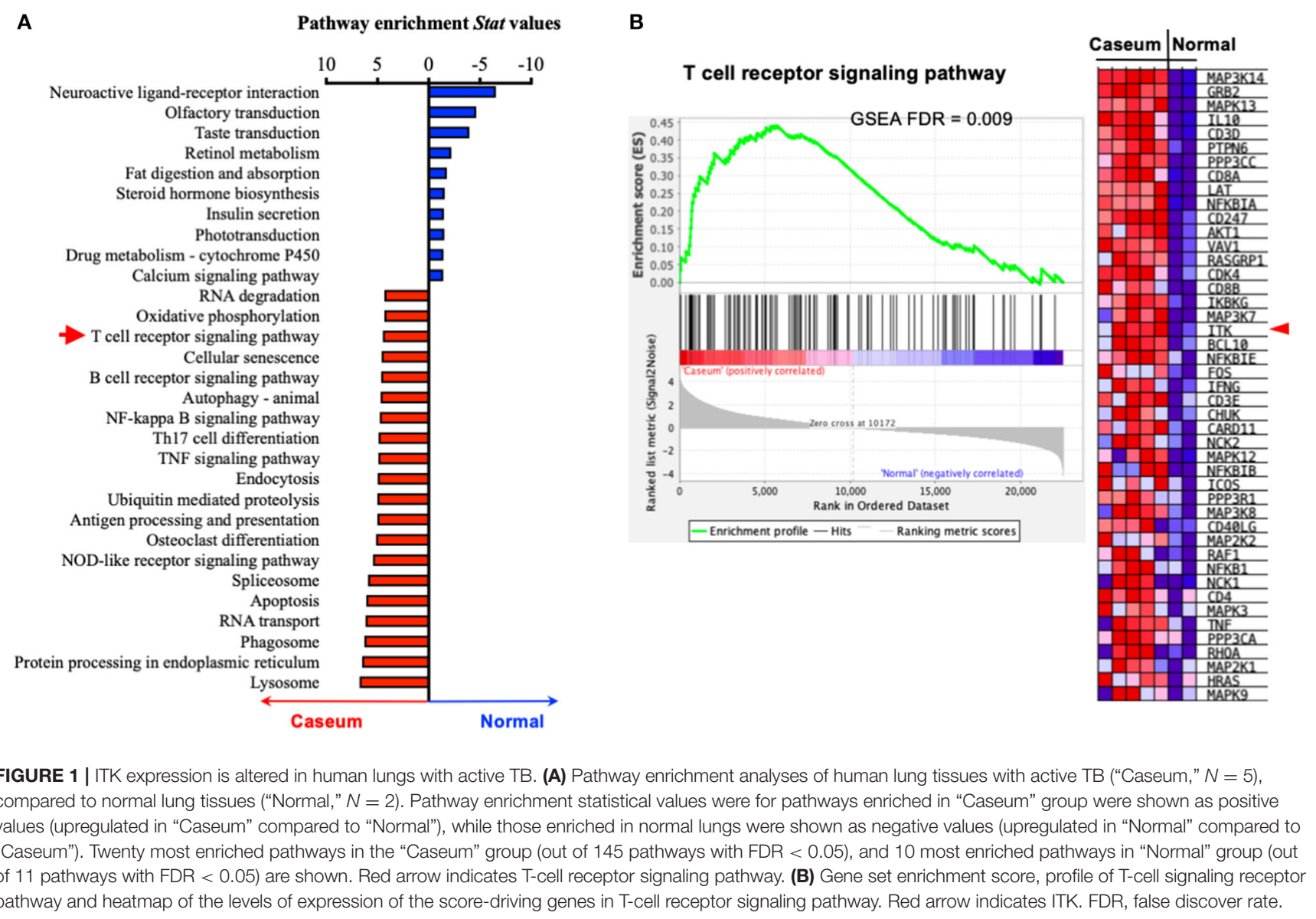


(Sigma). To stain for nuclear transcription factors Foxp3 and Ki67, following surface staining, cells were fixed, permeabilized, and stained using Foxp3 staining buffer set (eBioscience). All flow cytometry data were acquired on LSRII (BD Biosciences) and analyzed in FlowJo (Tree Star, Ashland, OR).

\section{Statistical Analysis}

Two-tailed Student's $t$-test and two-way analysis of variance (ANOVA) between groups were performed using Prism (GraphPad, San Diego, CA), with $p<0.05$ considered statistically significant. "NS" indicates differences that are not significant.

\section{RESULTS}

\section{TCR/ITK Signaling Components Are Upregulated in Active Tuberculosis in Humans}

The progression of human active TB disease and transmission involves the development of the caseous granuloma, in which both $M t b$ and the immune response are active (53). We have previously isolated human granulomata from patients with active TB (Caseum) and analyzed the transcriptomic profile in comparison to uninvolved lung tissue (normal) (53). Using pathway enrichment analyses, we found that genes of the TCR signaling were significantly enriched in the caseum tissue that was subjected to active TB, compared to uninvolved lung tissue (Figure 1). Among the enrichment score-driving critical genes of the TCR signaling, the levels of transcripts for ITK and its signaling components (5) such as LCK, GRB2, SLP76, NCK1, FYN, and PLCG are significantly upregulated in caseated granulomas compared to uninvolved lung tissue (Figure 1B). Among the genes that are significantly enriched in active TB, ITK locates in the hub of the TCR signaling pathway (Supplementary Figure 1). These data imply a role for ITK signaling in host immune activity during active TB.

\section{Itk Deficiency Results in Impaired Mtb Clearance and Increased Lung Pathology}

Given the observation that the TCR signaling pathway was upregulated in the face of active $\mathrm{TB}$ in human lungs and that ITK is a critical score-driving gene for the pathway enrichment (Figure 1), we sought to determine the role of ITK in host responses to $M t b$ infection. In murine models of Itk deficiency, despite no difference in animal mortality, we found that $M t b$ bacterial burden was significantly higher in the lungs in the absence of ITK 4 weeks post- $M t b$ infection (Figure 2A). Moreover, pulmonary pathology was elevated in the absence of ITK, with significantly larger areas in the airway affected at higher pathological scores (Figure 2B). Notably, compared to wild-type (WT) mice, the relative kinetics of bacterial growth in the lungs of $\mathrm{Itk}^{-/-}$and $\mathrm{Rag}^{-/-}$mice are similar $(61,62)$. These data suggest that the TCR/ITK signaling pathway regulates immune responses that contribute to limiting $M t b$ growth and controlling pulmonary inflammation 4 weeks postinfection.

\section{Itk-Deficient Mice Exhibit Altered Early Immune Responses to Mtb Infection}

The progression of human active TB disease and transmission involves the development of both innate and adaptive immunity. The relative abundance of lung phagocyte populations is extremely dynamic at the early stage of $M t b$ infection (63). Importantly, the various phagocytes in the lung provide different environments for $M t b$ and reveal distinct permissiveness for the growth of $M t b(64,65)$. We thus analyzed populations of innate immune cells in both WT and Itk-deficient mice infected with $M t b$ that constitutively express fluorescent protein mCherry, which allows mapping of the cellular location of intracellular bacteria. During early-stage infection, we
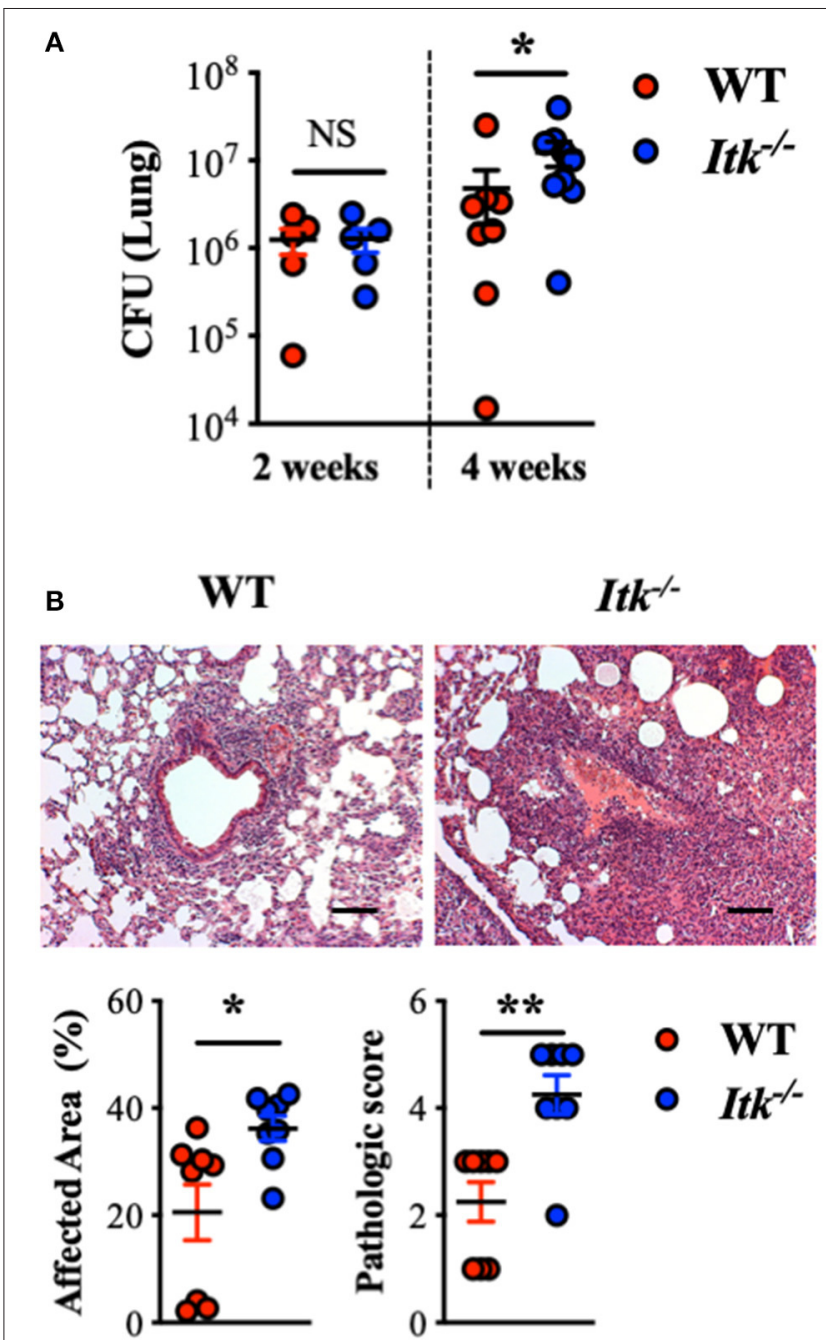

- WT - $\mathbf{I t} \boldsymbol{k}^{-}$

FIGURE 2 | Itk deficiency results in impaired bacterial clearance and increased pulmonary pathology post-Mtb infection in mice. WT and $/ t k^{-/-}$mice were infected with $10^{3} \mathrm{CFU}$ of $\mathrm{Mtb}$ (intranasal delivery) and analyzed 2 and 4 weeks postinfection. (A) CFU in WT and $/ t k^{-/-}$mice 2 and 4 weeks postinfection. (B) Representative histology, summary of affected area, and histological scoring of WT and $/ t k^{-/-}$lungs of mice 4 weeks post-Mtb infection. ${ }^{*} p<0.05$, ${ }^{* *} p<$ 0.01 by Student's $t$-test. Scale bar $=100 \mu \mathrm{m} . N=5-10$. Data were presented as mean \pm SEM and represent results of three independent experiments. 
A

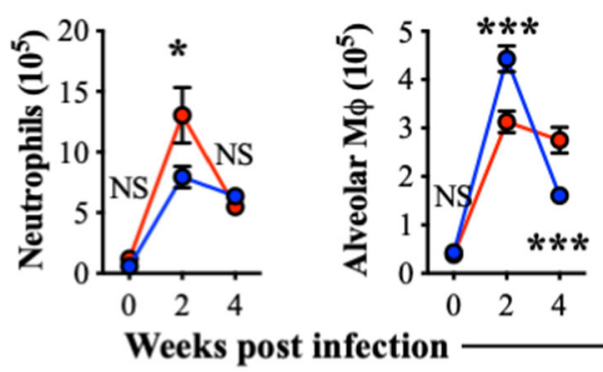

B $\%$ of $\mathrm{Mtb}^{+}$
$\left(\mathrm{m} \mathrm{Cherry}^{+}\right)$
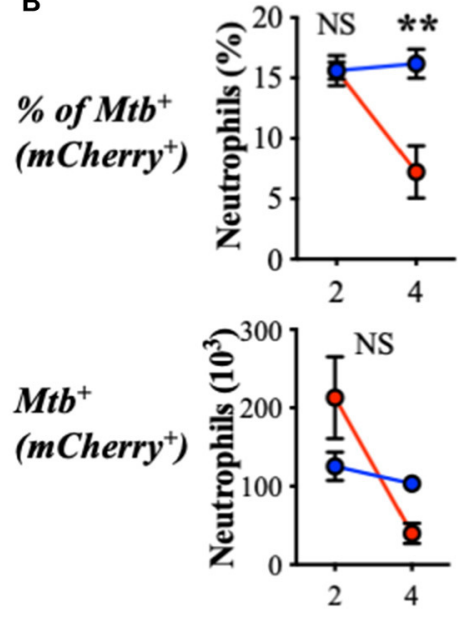
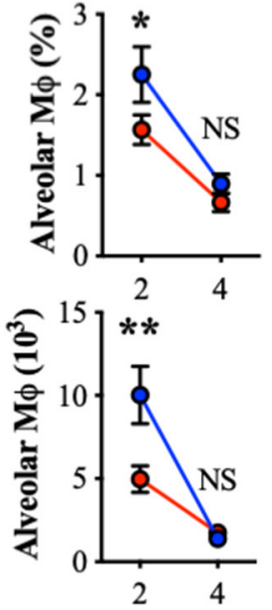
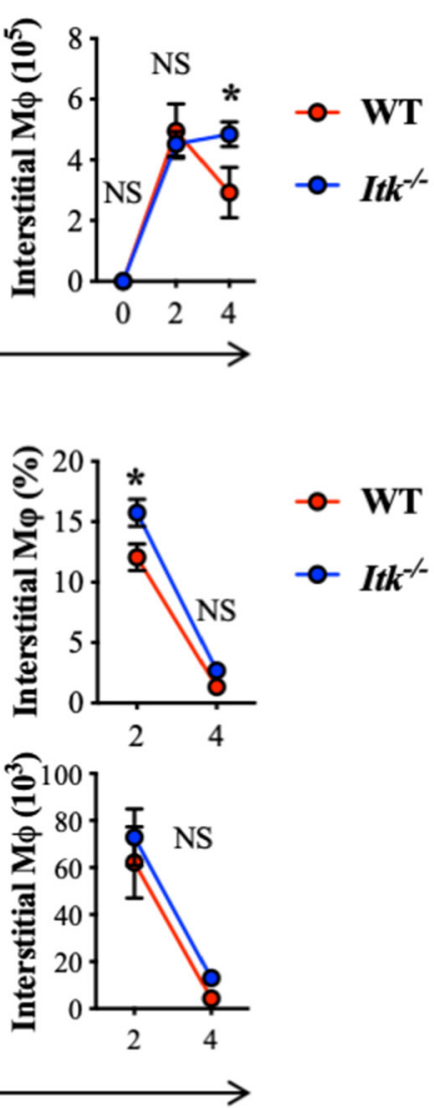

FIGURE 3 | ITK regulates innate myeloid immune response in mice during $M$ tb infection. WT and $/ t^{-/-}$mice were infected with $10^{3}$ CFU of mCherry-Mtb, and lungs

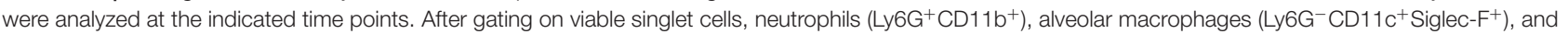
interstitial macrophages ( $\mathrm{Ly} 6 \mathrm{G}^{-}$Siglec- $\mathrm{F}^{-} \mathrm{CD} 11 \mathrm{~b}^{+} \mathrm{MHCl}^{+} \mathrm{CD}^{+} 4^{+}$) were analyzed. (A) Number of total neutrophils, alveolar macrophages, and interstitial macrophages isolated from the lungs of infected mice. (B) Percentage and number of mCherry-Mtb positive neutrophils, alveolar macrophages, and interstitial macrophages in the lung of the infected mice. NS, not significant; ${ }^{*} p<0.05,{ }^{\star \star} p<0.01,{ }^{\star \star *} p<0.001$ by two-way ANOVA with post hoc test. $N=5$. Data were presented as mean \pm SEM and represent results of three independent experiments.

observed increased total numbers of neutrophils and alveolar macrophages in the lung at 2 weeks postinfection in both WT and $I t k^{-/-}$mice (Figure 3A). Further analysis of the pulmonary immune cell populations revealed that, in the absence of ITK, the proportion of $M t b$-infected alveolar and interstitial macrophages was significantly higher early after infection (2 weeks); in addition, the proportion of $M t b$ infected neutrophils was significantly higher 4 weeks after infection (Figure 3). Effective removal of $M t b$-infected apoptotic neutrophils by macrophages, or efferocytosis, is considered beneficial for host defense (66). The failed clearance of infected neutrophils in Itk-deficient mice at 4 weeks suggests that Itk may be involved in regulating efferocytosis of lung macrophages. Both alveolar macrophages and neutrophils have been demonstrated as permissive cell types in $M t b$ infection by providing a hospitable environment for optimal bacterial growth $(64,65)$. The increased proportion of $M t b$ infected neutrophils in the absence of ITK is associated with the increased bacterial burden at 4 weeks, suggesting that bacterial burden may be attributed to this difference. Therefore, these data suggest that ITK regulates the dynamic of lung phagocytes and contributes to host protection against $M t b$ infection.

ITK is highly expressed in T-cell lineages including $\gamma \delta$ and $\alpha \beta$ T cells. To further determine whether the absence of ITK affects $\mathrm{T}$-cell and other related lymphocyte responses during $M t b$ infection, we also analyzed the abundance of $\gamma \delta \mathrm{T}$ cells, NK cells, NKT cells, and $\alpha \beta$ T cells, including total $\alpha \beta$ T cells, $\mathrm{CD}^{+}$conventional $\alpha \beta \mathrm{T}$ cells, $\mathrm{CD}^{+} \alpha \beta \mathrm{T}$ cells, and $\mathrm{CD}^{+}{ }^{+}$ Foxp $3^{+}$regulatory $\mathrm{T}$ (Treg) cells. Comparable numbers of $\gamma \delta$ $\mathrm{T}$ cells, NKT cells, and $\mathrm{CD}^{+} \alpha \beta \mathrm{T}$ cells were observed in WT and Itk-deficient mice infected with $M t b$, while NK cells and $\mathrm{CD}^{+} \alpha \beta$ T cells were significantly increased, and Foxp $3^{+}$ Treg cells were significantly reduced in the absence of ITK (Figure 4). These results seemed surprising, as a reduced number of Treg cells accompanied by increased numbers of $\mathrm{CD}^{+}$ $\alpha \beta \mathrm{T}$ cells may suggest a more active immune response. The hosts' ability to limit bacterial growth and control pulmonary 

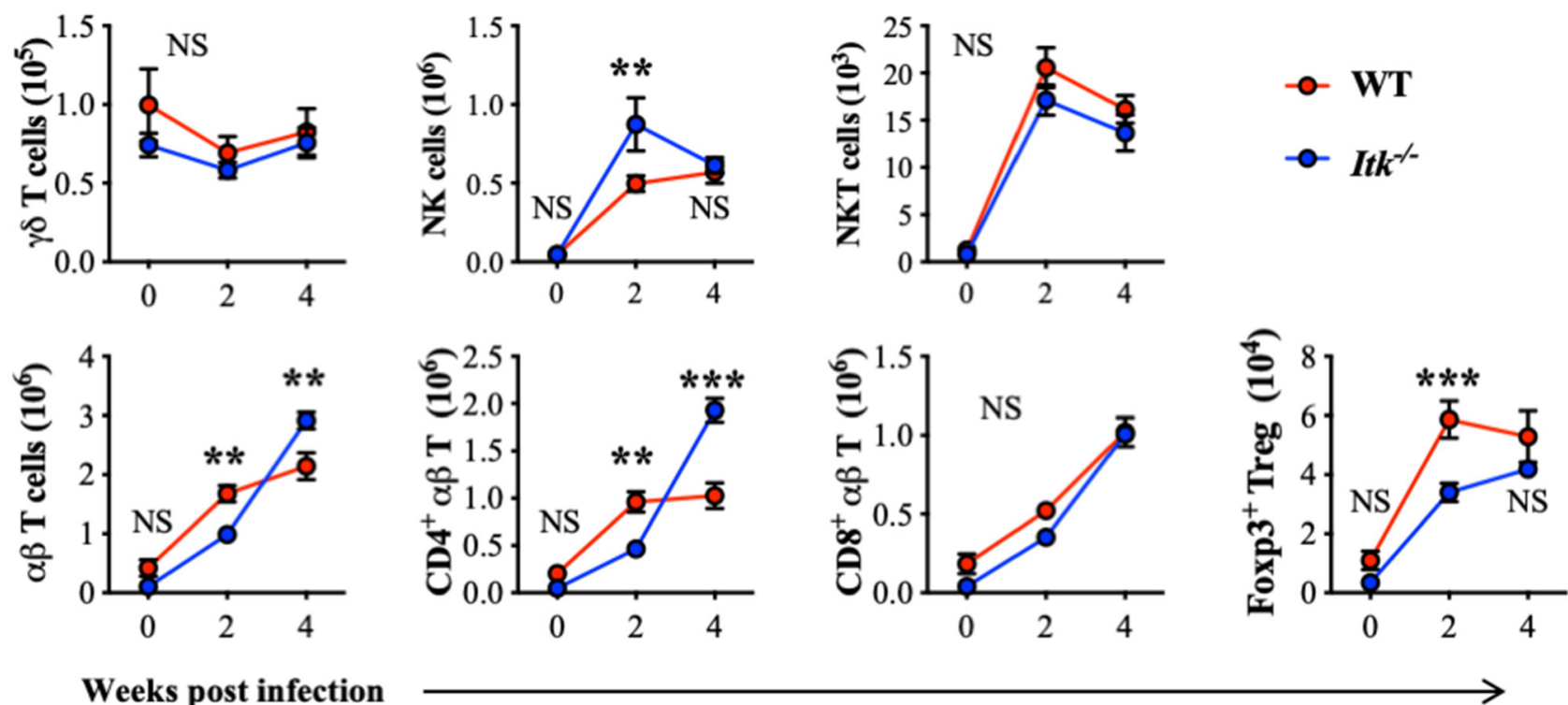

\section{Weeks post infection}

FIGURE 4 | Itk deficiency alters lymphocyte profile in the lung during Mtb infection. WT and Itk ${ }^{-/-}$mice were infected as in Figure $\mathbf{3}$, and lungs were analyzed at the indicated time points. After gating on viable singlet cells, lymphocytes including $\gamma \delta \mathrm{T}$ cells $\left(\mathrm{TCR} \gamma \delta^{+} \mathrm{TCR} \beta^{-}\right), \mathrm{NK}$ cells $\left(\mathrm{TCR} \gamma \delta^{-} \mathrm{TCR} \beta^{-} \mathrm{NK} 1.1^{+}\right)$, $\mathrm{NKT}$ cells

$\left(\mathrm{TCR} \gamma \delta^{-} \mathrm{TCR} \beta^{+} \mathrm{NK} 1.1^{+}\right)$, and $\alpha \beta$ T cells $\left(\mathrm{TCR} \gamma \delta^{-} \mathrm{TCR} \beta^{+}\right)$, and among $\alpha \beta T$ cells, CD4 ${ }^{+}$conventional T cells, CD8 ${ }^{+}$cells, and CD4 ${ }^{+}$Foxp $3^{+}$Treg cells were analyzed. $N$ $=5-9$. Numbers of the indicated cell types were presented as mean \pm SEM and represent results of three independent experiments. NS, not significant; ${ }^{\star \star} p<0.01$,

${ }^{* * *} p<0.001$ by two-way ANOVA with post hoc test.

inflammation was, however, impaired in the absence of ITK. A possible explanation could be that the effector activity of the lymphocytes observed in the infected airway against $M t b$ may differ. These effector immune responses could involve innate lymphocyte activities, as well as $M t b$ antigen-specific adaptive lymphocyte functions.

\section{ITK Is Critical for $\gamma \delta$ T-Cell-Derived IL-17A Production During Mtb Infection}

It has been reported that IL-17A is protective during primary infection of virulent $M t b$ (67), and IL-17A is predominantly produced by $\gamma \delta \mathrm{T}$ cells in the lungs early after $M t b$ infection (68). Indeed, while we detected significant IL-17A production by $\gamma \delta \mathrm{T}$ cells in the lungs of WT mice infected with $M t b$ (red foreground in Figures 5A-C), very limited IL-17A was produced by the conventional $\mathrm{CD}^{+} \alpha \beta$ Th17 cells (gray background in Figure 5A, as well as in Figure 5D). Interestingly, in the absence of ITK, there was a marked reduction in IL-17A-producing $\gamma \delta \mathrm{T}$ cells in the lung (Figures 5A-C). In contrast to the significant levels of IL-17A production in $\gamma \delta$ $\mathrm{T}$ cells, IL-17A production by $\mathrm{CD}^{+}$and $\mathrm{CD}^{+} \alpha \beta \mathrm{T}$ cells during $M t b$ infection was minimal (Figure 5B vs. Figure 5D). Furthermore, in the absence of ITK, unlike $\gamma \delta$ T-cell-derived IL-17A that was significantly impaired, IL-17A production by $\mathrm{CD}^{+}$and $\mathrm{CD}^{+} \alpha \beta \mathrm{T}$ cells did not exhibit overt differences, although the proportion of those cells making IL-17A was quite low (Figure 5D).

\section{Itk Deficiency Has Minimal Impact on Antigen-Specific $\alpha \beta$ T-Cell Responses During Mtb Infection}

Our data above supports a strong role of ITK in promoting the IL-17A-producing effector $\gamma \delta \mathrm{T}$ cells during $M t b$ infection. It is possible that $\alpha \beta$ T-cell effector functions were also altered in the absence of ITK and further contributed to the impaired bacterial clearance and enhanced lung pathology as observed in Figure 2. To determine whether ITK regulates $\alpha \beta$ T-cell effector function, we stimulated cells isolated from the lungs of the infected mice 4 weeks postinfection. We found that bulk T-cell activation by PMA and ionomycin suggested that ITK is not required for $\mathrm{CD}^{+}$and $\mathrm{CD}^{+} \alpha \beta \mathrm{T}$ cells to produce effector cytokines tumor necrosis factor alpha (TNF- $\alpha$ ) and interferongamma (IFN- $\gamma$ ) during $M t b$ infection (Figure 6A). Moreover, to our surprise, stimulation of $M t b$ antigen-specific $\mathrm{CD} 4^{+} \alpha \beta$ T cells with ESAT- ${ }_{4-17}$ (MHCII-restricted epitope), or CD8 ${ }^{+}$ $\alpha \beta$ T cells with TB10.4 $4_{4-11}$ (MHCI-restricted epitope) revealed no difference in production of TNF- $\alpha$ and IFN- $\gamma$ by these cells in the absence of ITK (Figure 6B). Along with the data above, our results suggest that the major protective role of ITK during $M t b$ infection might be executed through ITK-mediated IL-17A production by $\gamma \delta \mathrm{T}$ cells.

\section{Itk Regulates $\gamma \delta$ T Cell but Not $\alpha \beta$ T-Cell Proliferation During Mtb Infection}

Itk deficiency led to significantly impaired effector $\gamma \delta \mathrm{T}$ cells (Figure 5) but not $\alpha \beta \mathrm{T}$ cells (Figure 6). These might be 


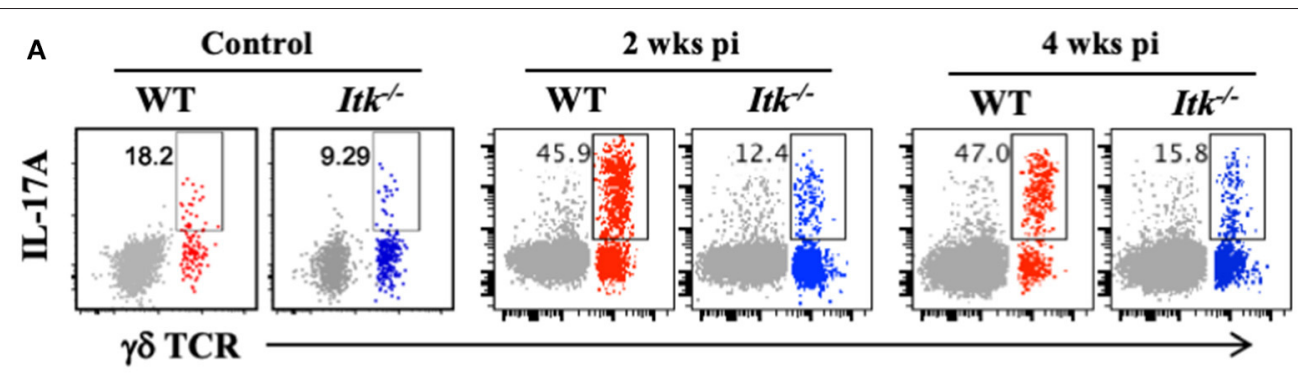

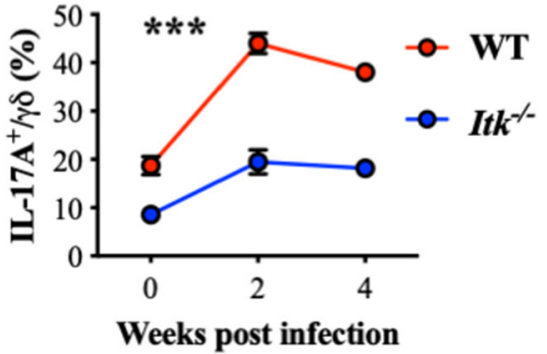

C

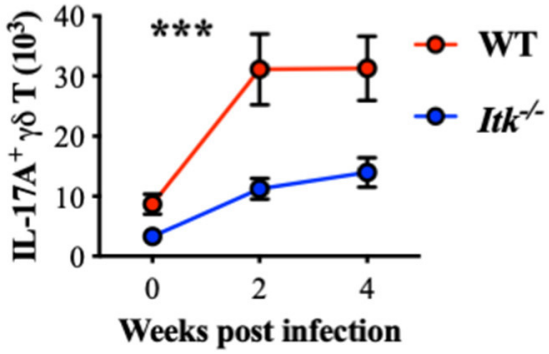

D

$\mathrm{CD4}^{+} \alpha \beta \mathrm{T}$ cells

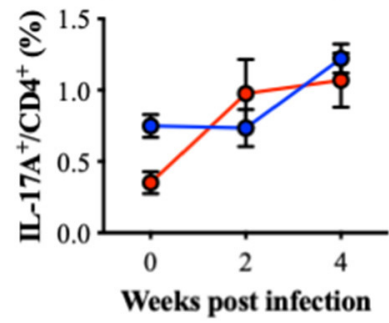

CD8 $^{+} \alpha \beta$ T cells

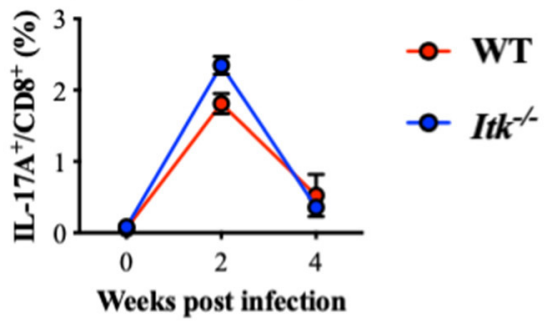

FIGURE 5 | Itk deficiency impairs lung $\gamma \delta$ T-cell-derived IL-17A production during Mtb infection. WT and Itk ${ }^{-1-}$ mice were infected as in Figure 3, and lungs were analyzed at the indicated time points. Cells isolated from the lungs were stimulated with PMA and ionomycin, in the presence of BFA and monensin, followed by intracellular cytokine staining. (A) Representative FACS plots for IL-17A production by $\gamma \delta$ T cells. Production of CD4 ${ }^{+} \alpha \beta T$ cells is shown as gray background. (B) Percentages and (C) number of IL-17A-producing $\gamma \delta$ T cells. (D) Percentages of IL-17A-producing CD4 ${ }^{+}$and CD8 ${ }^{+} \alpha \beta$ T cells. ${ }^{\star \star *} p<0.001$ by two-way ANOVA with post hoc test. $N=5-9$. Numbers of the indicated cell types were presented as mean \pm SEM and represent results of three independent experiments.

the results of differential requirement of ITK signaling in Tcell expansion. Using proliferative maker Ki67 to detect T-cell proliferation, we found that $M t b$-driven early proliferation of $\gamma \delta$ $\mathrm{T}$ cells was severely impaired in ITK deficiency (Figure 7, top panel), but not the $\mathrm{CD}^{+}$and $\mathrm{CD}^{+} \alpha \beta$ T-cell subsets (Figure 7, middle and bottom panels). These data, in part, explain the selective defect of effector $\gamma \delta$ T-cell development in Itk-deficient mice during $M t b$ infection.

\section{DISCUSSION}

The immune cells that control $M t b$ include macrophages, neutrophils, and T-cell populations $(2,3)$. The TCR pathway is elevated in active $M t b$ infection in human lung, and ITK is a major component of this pathway; however, its role in the T-cell response to $M t b$ is not known. Here, we demonstrate a protective role of ITK in $M t b$ infections in murine models, with a particular role in the ability of lung $\gamma \delta \mathrm{T}$ cells to produce IL$17 \mathrm{~A}$, which is associated with $M t b$ residence in lung neutrophils.
These findings have important implications for understanding the T-cell immune response to $M t b$ and the role of ITK in this process.

In humans, $M t b$ infects via inhalation of a low dose of aerosolized bacteria; therefore, low-dose aerosol inoculation would better mimic the nature of $M t b$ infection in humans. However, in the absence of the ability to perform aerosolized infections, the standard experimental protocol of $M t b$ infection in mice is 1,000 CFU via intranasal inoculation (69-72). Monocytes play an essential role in initiating T-cell responses in the lung against $M t b$ infection (73), and using this standard protocol of $M t b$ infection in mice, we previously observed monocytosis (64), similar to what has been reported in other studies using aerosolized low-dose infection protocols $(74,75)$. Using intranasal inoculation with 1,000 CFU of $M t b$ in mice, we observed that the numbers of host myeloid cells infiltrating to the lung during $M t b$ infection are significantly altered in the absence of ITK. Alveolar macrophages are considered as the preferred replicating niche for $M t b$ and promote the early 


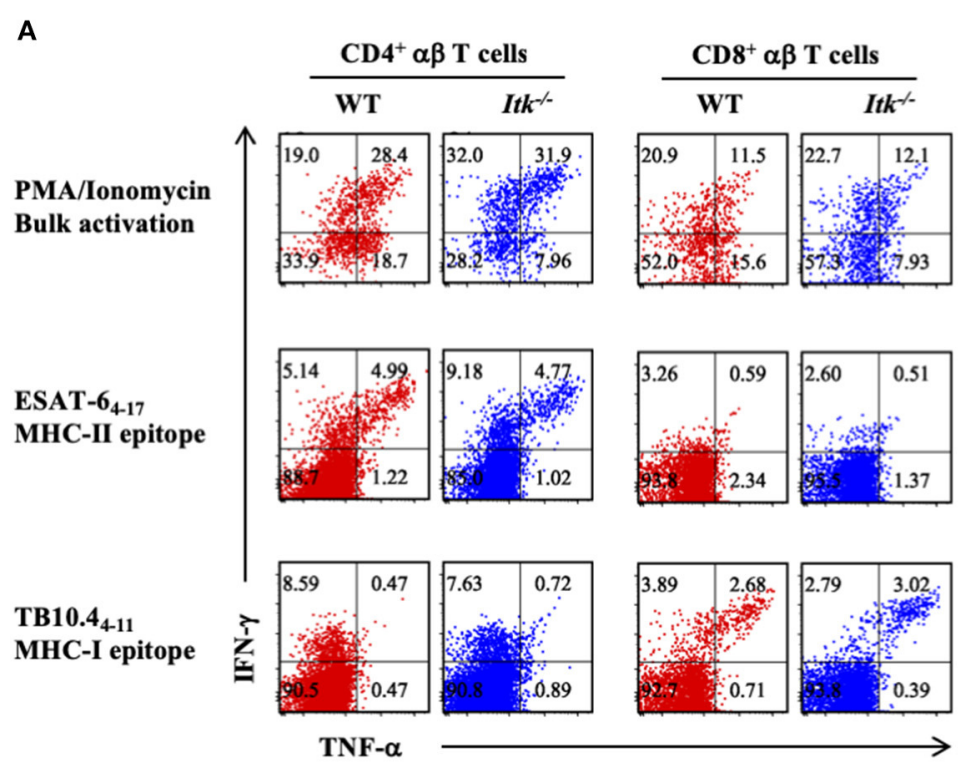

B

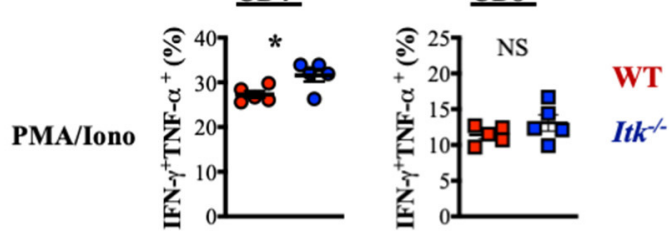

ESAT-6 4-17 $^{-1}$
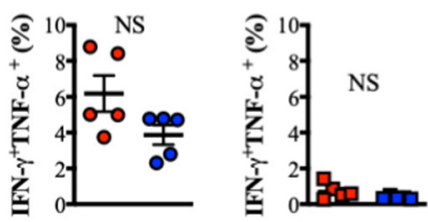

TB10.4 $_{4-11}$

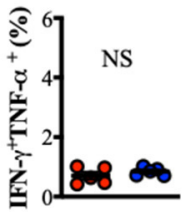

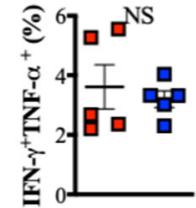

FIGURE 6 | Itk deficiency has minimal impact on lung antigen-specific $\alpha \beta$ effector T cells during $M$ tb infection. WT and ltk- ${ }^{-1}$ mice were infected as in Figure 3 and analyzed 4 weeks postinfection. Cells isolated from the lungs were stimulated with PMA and ionomycin (for bulk T-cell activation), MHCII-restricted Mtb epitope ESAT-6 $4_{-17}$ (for antigen-specific CD4+ T-cell activation), or MHCl- restricted Mtb epitope TB10.4-11 (for antigen-specific CD8 ${ }^{+}$T-cell activation), in the presence of BFA and monensin, followed by intracellular cytokine staining. (A) Representative FACS plots for IFN- $\gamma$ and TNF- $\alpha$ production by CD $4^{+}$and CD8 ${ }^{+} \alpha \beta$ T cells under the indicated stimulating conditions. (B) Summary of percentages of IFN- $\gamma$ and TNF- $\alpha$-producing CD4 ${ }^{+}$and CD8 ${ }^{+} \alpha \beta$ T cells under the indicated stimulating conditions. $N$ $=5$. Data were presented as mean \pm SEM and represent results of three independent experiments. NS, not significant; ${ }^{*} p<0.05$ by Student's $t$-test.

A

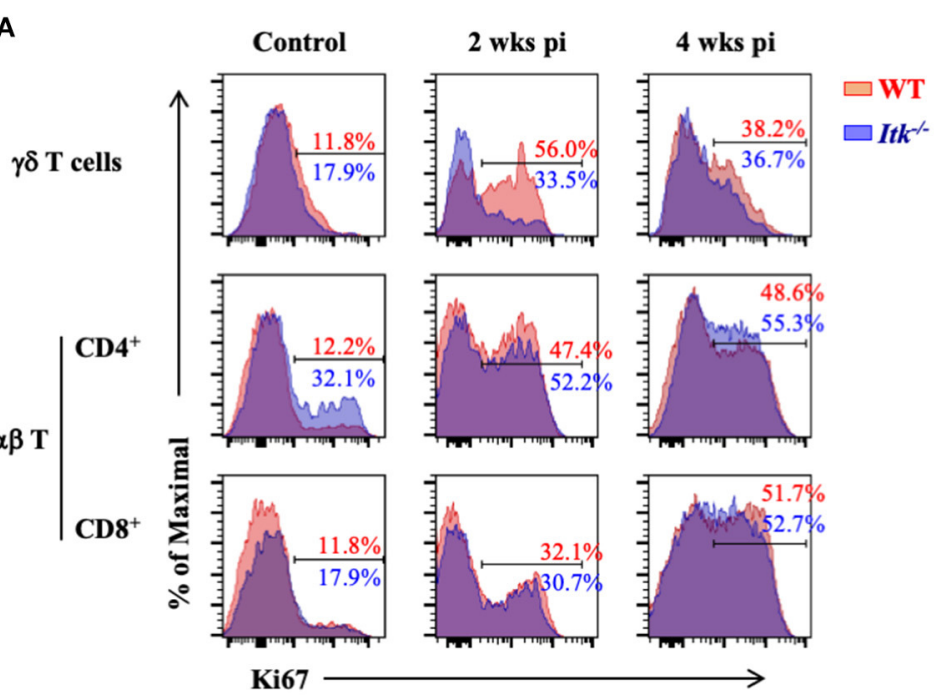

Control
B
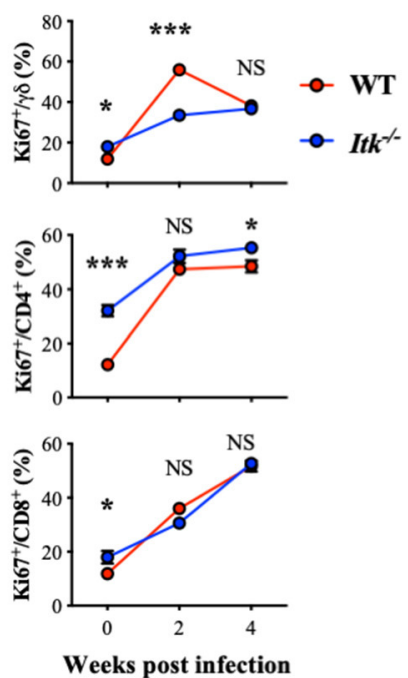

FIGURE 7 | Itk deficiency impairs lung $\gamma \delta$ but not $\alpha \beta$ T-cell proliferation during Mtb infection. WT and ltk ${ }^{-/-}$mice were infected as in Figure 3 and analyzed at the indicated time points. Cells isolated from the lungs were analyzed via nuclear staining. (A) Representative FACS plots for Ki67 expression by $\gamma \delta \mathrm{T}$ cells and CD4+ and $\mathrm{CD}^{+} \alpha \beta$ T cells at the indicated time points postinfection. (B) Summary of percentages of $\mathrm{Kl}^{+} 7^{+}$cells among $\gamma \delta \mathrm{T}$ cells and CD4+ and CD8 ${ }^{+} \alpha \beta \mathrm{T}$ cells. $N=5-9$. Data were presented as mean \pm SEM and represent results of three independent experiments. NS, not significant; ${ }^{\star} p<0.05$, ${ }^{\star \star \star} p<0.001$ by two-way ANOVA with post hoc test.

stage of infection $(64,76)$. In Itk-deficient mice, there are more alveolar macrophages harboring $M t b$, suggesting a more permissive cellular environment in the lung. Moreover, although fewer neutrophils are present in the lung in the absence of
ITK, there are more $M t b$ resident in neutrophils at 4 weeks postinfection. The redistribution of $M t b$ in different phagocytes in the absence of ITK appears to correlate with the increased bacterial burden in the lung 4 weeks postinfection. Other than 
$\mathrm{T}$ cells, ITK has been indicated to regulate functions of innate immune cells such as mast cells $(77,78)$. However, potential intrinsic functions of ITK in lung macrophages and neutrophils during $M t b$ infection would merit further studies.

Activation of $\gamma \delta \mathrm{T}$ cells for IL-17A production is severely impaired in Itk-deficient mice and very likely responsible for the resultant neutrophil recruitment early after infection(s), as well as the increased neutrophil resident $M t b$ population later in infection. Indeed, we have shown that ITK can regulate $\gamma \delta \mathrm{T}$ cell development and function in mouse (48), and while there was no apparent difference in peripheral blood $\gamma \delta \mathrm{T}$-cell numbers in humans carrying ITK mutations (12), the normal range for $\gamma \delta$ $\mathrm{T}$ cells varies quite widely by anatomical location, as well as by geography and ethnicity (79). Despite relatively normal antigenspecific $\alpha \beta$ T-cell responses, our results identify ITK signaling as an essential player for the IL-17A production by $\gamma \delta \mathrm{T}$ cells, the predominant source of IL-17A in $M t b$-infected lungs (68). ITK exhibited a $\gamma \delta$ T cell-specific function, as compared to $\alpha \beta$ T cells, in driving T-cell proliferation during early immune responses to $M t b$ infections. Our work suggests that ITK deficiency in humans may lead to $\gamma \delta$ T-cell deficiency in expansion and production of IL-17A, in the face of $M t b$ infection.

We and others have previously reported a role for ITK signaling in regulating Foxp $3^{+}$regulatory $\mathrm{T}$ (Treg) cell development and function $(41,80)$. In the absence of ITK, the proportion of Treg cells among $\mathrm{CD}^{+}{ }^{+} \mathrm{T}$ cells in the lymphoid organs of naive mice is increased, and the differentiation of inducible Treg cells from $\mathrm{CD}^{+}$naive $\mathrm{T}$ cells in vitro is also enhanced $(41,80)$. The role of ITK in Treg cell responses in the lung during $M t b$ infection was, however, unclear. In mouse model of $M t b$ infection, we observed higher $M t b$ burdens, higher lung pathological scores and reduced numbers of Treg cells found in the lungs in Itk-deficient mice, compared to those in the infected WT mice (Figure 4). Tissue damage may be explained by excessive growth of the pathogen and/or immunopathology. Indeed, we observed impaired $\gamma \delta \mathrm{T}$ cell expansion and $\gamma \delta \mathrm{T}$ cellderived IL-17A production in $M t b$-infected $I t k$-deficient mice but no overt differences in other immune effectors. The decrease in Treg numbers in the lung during $M t b$ infection in the absence of ITK may explain higher levels of immunopathology potentially due to impaired immunomodulatory function. Future research using murine models with conditional deletion of Itk specifically in Foxp $3^{+}$Treg cells would allow more in-depth investigation of the role of ITK in Treg cells during Mtb infection.

Taken together, these findings suggest a potential role for ITK in active $\mathrm{TB}$ in humans, in addition to its known connection with primary immunodeficiency, susceptibility to EBV, lymphoproliferative diseases, and asthma (12, 50, 51). These findings also have important implications for human genetics associated with susceptibility to $M t b$ due to altered immune responses and molecular signals modulating host immunity that controls the progression of active tuberculosis.

Our findings support a role of ITK signaling in promoting protective immune responses against $M t b$, in particular, $\gamma \delta \mathrm{T}$ cell expansion and production of IL-17A, which could contribute to the modulation of tuberculosis, especially in infections with highly virulent bacterial strains in which IL-17A has been shown to play an essential protective role (67). However, our work also sounds a note of caution for the potential use of compounds such as Ibrutinib that inhibit the related kinase BTK as well as ITK (81). Given the potential for inhibition of ITK, patients being treated with Ibrutinib may need to be monitored for infection or potential reactivation of latent $M t b$.

\section{DATA AVAILABILITY STATEMENT}

The datasets generated for this study can be found in the Gene Expression Omnibus under accession number GSE20050.

\section{ETHICS STATEMENT}

The animal study was reviewed and approved by the Institutional Animal Care and Use Committees at Cornell University.

\section{AUTHOR CONTRIBUTIONS}

LH, MM, NN, JE, CL, and WH performed the experiments. $\mathrm{LH}, \mathrm{TS}, \mathrm{AA}$, and $\mathrm{WH}$ analyzed and interpreted data. $\mathrm{LH}, \mathrm{AA}$, and $\mathrm{WH}$ wrote the manuscript. KY performed bioinformatic analyses. DR contributed reagents and intellectual input. AA and WH conceived research and designed experiments.

\section{FUNDING}

This work was supported in part by grants from the National Institutes of Health (AI120701 and AI138570 to AA, AI129422 to AA and WH, GM130555 Sub-6610 to WH, and AI134183 to DR), and a Pilot Grant (to WH) from LSU-Tulane COBRE Center for Experimental Infectious Disease Research (funded by NIH P30GM110760). JE was supported by a training program in Biomedical and Bioengineering at Cornell University (funded by NIH T32EB023860). MM is a recipient of the Pathobiological Sciences Graduate Program Fellowship in the School of Veterinary Medicine at the Louisiana State University.

\section{ACKNOWLEDGMENTS}

We thank Amie Redko for the animal care and Ling Zhang for the technical assistance.

\section{SUPPLEMENTARY MATERIAL}

The Supplementary Material for this article can be found online at: https://www.frontiersin.org/articles/10.3389/fimmu. 2019.03103/full\#supplementary-material

Supplementary Figure 1 | Gene enrichment profile of the TCR/TK signaling in human lungs with active TB. Genes in the TCR signaling pathways were rendered with their positions and connections in the pathway, with colored codes indicating the $\log _{2}$-fold change comparing levels of gene expression in caseous to those in normal tissues. Red indicates upregulation in caseous samples while blue indicates downregulation. Note that ITK is one of the central components of the TCR signaling pathway.

Supplementary Table 1 | Summary of pathways that exhibited an up- or down-regulated trend in caseum samples compared to normal tissues. 


\section{REFERENCES}

1. Global Tuberculosis Report 2019. Geneva: World Health Organization (2019).

2. O'Garra A, Redford PS, McNab FW, Bloom CI, Wilkinson RJ, Berry MP. The immune response in tuberculosis. Annu Rev Immunol. (2013) 31:475-527. doi: 10.1146/annurev-immunol-032712-095939

3. de Martino M, Lodi L, Galli L, Chiappini E. Immune response to Mycobacterium tuberculosis: a narrative review. Front Pediatr. (2019) 7:350. doi: 10.3389/fped.2019.00350

4. Boisson-Dupuis S, Bustamante J, El-Baghdadi J, Camcioglu Y, Parvaneh $\mathrm{N}$, El Azbaoui $\mathrm{S}$, et al. Inherited and acquired immunodeficiencies underlying tuberculosis in childhood. Immunol Rev. (2015) 264:103-20. doi: $10.1111 / \mathrm{imr} .12272$

5. Andreotti AH, Schwartzberg PL, Joseph RE, Berg LJ. T-cell signaling regulated by the Tec family kinase, Itk. Cold Spring Harb Perspect Biol. (2010) 2:a002287. doi: 10.1101/cshperspect.a002287

6. Tangye SG, Palendira U, Edwards ES. Human immunity against EBVlessons from the clinic. J Exp Med. (2017) 214:269-83. doi: 10.1084/jem.201 61846

7. Mansouri D, Mahdaviani SA, Khalilzadeh S, Mohajerani SA, Hasanzad M, Sadr S, et al. IL-2-inducible T-cell kinase deficiency with pulmonary manifestations due to disseminated Epstein-Barr virus infection. Int Arch Allergy Immunol. (2012) 158:418-22. doi: 10.1159/000333472

8. Linka RM, Risse SL, Bienemann K, Werner M, Linka Y, Krux F, et al. Lossof-function mutations within the IL-2 inducible kinase ITK in patients with EBV-associated lymphoproliferative diseases. Leukemia. (2012) 26:963-71. doi: 10.1038/leu.2011.371

9. Huck K, Feyen O, Niehues T, Ruschendorf F, Hubner N, Laws HJ, et al. Girls homozygous for an IL-2-inducible $\mathrm{T}$ cell kinase mutation that leads to protein deficiency develop fatal EBV-associated lymphoproliferation. J Clin Invest. (2009) 119:1350-8. doi: 10.1172/JCI37901

10. Bienemann K, Borkhardt A, Klapper W, Oschlies I. High incidence of EpsteinBarr virus (EBV)-positive Hodgkin lymphoma and Hodgkin lymphomalike B-cell lymphoproliferations with EBV latency profile 2 in children with interleukin-2-inducible T-cell kinase deficiency. Histopathology. (2015) 67:607-16. doi: 10.1111/his.12677

11. Veillette A, Perez-Quintero LA, Latour S. X-linked lymphoproliferative syndromes and related autosomal recessive disorders. Curr Opin Allergy Clin Immunol. (2013) 13:614-22. doi: 10.1097/ACI.0000000000000008

12. Ghosh S, Bienemann K, Boztug K, Borkhardt A. Interleukin-2-inducible Tcell kinase (ITK) deficiency - clinical and molecular aspects. J Clin Immunol. (2014) 34:892-9. doi: 10.1007/s10875-014-0110-8

13. Cohen JI. Primary immunodeficiencies associated with EBV disease. Curr Top Microbiol Immunol. (2015) 390:241-65. doi: 10.1007/978-3-319-22822-8_10

14. Eken A, Cansever M, Somekh I, Mizoguchi Y, Zietara N, Okus FZ, et al. Genetic deficiency and biochemical inhibition of ITK affect human Th17, Treg, and innate lymphoid cells. J Clin Immunol. (2019) 39:391-400. doi: 10.1007/s10875-019-00632-5

15. Qi Q, Huang W, Bai Y, Balmus G, Weiss RS, August A. A unique role for ITK in survival of invariant NKT cells associated with the p53-dependent pathway in mice. J Immunol. (2012) 188:3611-9. doi: 10.4049/jimmunol.1102475

16. Qi Q, Xia M, Bai Y, Yu S, Cantorna M, August A. Interleukin-2-inducible T cell kinase (Itk) network edge dependence for the maturation of iNKT cell. $J$ Biol Chem. (2011) 286:138-46. doi: 10.1074/jbc.M110.148205

17. Felices M, Berg LJ. The Tec kinases Itk and Rlk regulate NKT cell maturation, cytokine production, and survival. J Immunol. (2008) 180:300718. doi: 10.4049/jimmunol.180.5.3007

18. Gadue P, Stein PL. NK T cell precursors exhibit differential cytokine regulation and require Itk for efficient maturation. J Immunol. (2002) 169:2397-406. doi: 10.4049/jimmunol.169.5.2397

19. Liao XC, Littman DR. Altered $\mathrm{T}$ cell receptor signaling and disrupted $\mathrm{T}$ cell development in mice lacking Itk. Immunity. (1995) 3:757-69. doi: 10.1016/1074-7613(95)90065-9

20. Bachmann MF, Littman DR, Liao XC. Antiviral immune responses in Itk-deficient mice. J Virol. (1997) 71:7253-7. doi: 10.1128/JVI.71.10.7253-7257.1997

21. Liao XC, Littman DR, Weiss A. Itk and Fyn make independent contributions to T cell activation. J Exp Med. (1997) 186:2069-73. doi: $10.1084 /$ jem.186.12.2069
22. Schaeffer EM, Debnath J, Yap G, McVicar D, Liao XC, Littman DR, et al. Requirement for Tec kinases Rlk and Itk in T cell receptor signaling and immunity. Science. (1999) 284:638-41. doi: 10.1126/science.284.5414.638

23. Liu KQ, Bunnell SC, Gurniak CB, Berg LJ. T cell receptor-initiated calcium release is uncoupled from capacitative calcium entry in Itk-deficient T cells. $J$ Exp Med. (1998) 187:1721-7. doi: 10.1084/jem.187.10.1721

24. Atherly LO, Lucas JA, Felices M, Yin CC, Reiner SL, Berg LJ. The Tec family tyrosine kinases Itk and Rlk regulate the development of conventional $\mathrm{CD} 8^{+}$ T cells. Immunity. (2006) 25:79-91. doi: 10.1016/j.immuni.2006.05.012

25. Broussard C, Fleischacker C, Horai R, Chetana M, Venegas AM, Sharp $\mathrm{LL}$, et al. Altered development of $\mathrm{CD}^{+} \mathrm{T}$ cell lineages in mice deficient for the Tec kinases Itk and Rlk. Immunity. (2006) 25:93-104. doi: 10.1016/j.immuni.2006.05.011

26. Prince AL, Yin CC, Enos ME, Felices M, Berg LJ. The Tec kinases Itk and Rlk regulate conventional versus innate T-cell development. Immunol Rev. (2009) 228:115-31. doi: 10.1111/j.1600-065X.2008.00746.x

27. Prince AL, Watkin LB, Yin CC, Selin LK, Kang J, Schwartzberg PL, et al. Innate $\mathrm{PLZF}^{+} \mathrm{CD} 4{ }^{+}$alphabeta $\mathrm{T}$ cells develop and expand in the absence of Itk. $J$ Immunol. (2014) 193:673-87. doi: 10.4049/jimmunol.1302058

28. Prince AL, Kraus Z, Carty SA, Ng C, Yin CC, Jordan MS, et al. Development of innate $\mathrm{CD}^{+}$and $\mathrm{CD} 8^{+} \mathrm{T}$ cells in Itk-deficient mice is regulated by distinct pathways. J Immunol. (2014) 193:688-99. doi: 10.4049/jimmunol.1302059

29. Hu J, Sahu N, Walsh E, August A. Memory phenotype CD8 ${ }^{+} \mathrm{T}$ cells with innate function selectively develop in the absence of active Itk. Eur I Immunol. (2007) 37:2892-9. doi: 10.1002/eji.200737311

30. Hu J, August A. Naive and innate memory phenotype $\mathrm{CD} 4^{+} \mathrm{T}$ cells have different requirements for active Itk for their development. J Immunol. (2008) 180:6544-52. doi: 10.4049/jimmunol.180.10.6544

31. Huang W, Huang F, Kannan AK, Hu J, August A. ITK tunes IL-4-induced development of innate memory $\mathrm{CD}^{+} \mathrm{T}$ cells in a gammadelta $\mathrm{T}$ and invariant NKT cell-independent manner. J Leukoc Biol. (2014) 96:55-63. doi: 10.1189/jlb.1AB0913-484RR

32. Miller A, Wilcox H, Lai Z, Berg L. Signaling through Itk promotes $\mathrm{T}$ helper 2 differentiation via negative regulation of T-bet. Immunity. (2004) 21:67-80. doi: 10.1016/j.immuni.2004.06.009

33. Mueller C, August A. Attenuation of immunological symptoms of allergic asthma in mice lacking the tyrosine kinase ITK. J Immunol. (2003) 170:505663. doi: 10.4049/jimmunol.170.10.5056

34. Kannan A, Sahu N, Mohanan S, Mohinta S, August A. Itk modulates allergic airway inflammation by suppressing IFN $\gamma$ in naïve $\mathrm{CD} 4^{+}$T-cells. J Allergy Clin Immunol. (2013) 132:811-20.e1-5. doi: 10.1016/j.jaci.2013. 04.033

35. Kannan A, Lee Y, Qi Q, Huang W, Jeong AR, Ohnigian S, et al. Allelesensitive mutant, Itkas, reveals that Itk kinase activity is required for Th1, Th2, Th17, and iNKT-cell cytokine production. Eur I Immunol. (2015) 45:2276-85. doi: 10.1002/eji.201445087

36. Sahu N, Venegas AM, Jankovic D, Mitzner W, Gomez-Rodriguez J, Cannons $J \mathrm{~L}$, et al. Selective expression rather than specific function of Txk and Itk regulate Th1 and Th2 responses. I Immunol. (2008) 181:6125-31. doi: 10.4049/jimmunol.181.9.6125

37. Sahu N, Mueller C, Fischer A, August A. Differential sensitivity to Itk kinase signals for $\mathrm{T}$ helper 2 cytokine production and chemokine-mediated migration. J Immunol. (2008) 180:3833-8. doi: 10.4049/jimmunol.180.6.3833

38. Schaeffer EM, Yap GS, Lewis CM, Czar MJ, McVicar DW, Cheever AW, et al. Mutation of Tec family kinases alters T helper cell differentiation. Nat Immunol. (2001) 2:1183-8. doi: 10.1038/ni734

39. Gomez-Rodriguez J, Meylan F, Handon R, Hayes ET, Anderson SM, Kirby MR, et al. Itk is required for Th9 differentiation via TCR-mediated induction of IL-2 and IRF4. Nat Commun. (2016) 7:10857. doi: 10.1038/ncomms10857

40. Gomez-Rodriguez J, Sahu N, Handon R, Davidson TS, Anderson SM, Kirby $\mathrm{MR}$, et al. Differential expression of interleukin-17A and $-17 \mathrm{~F}$ is coupled to $\mathrm{T}$ cell receptor signaling via inducible T cell kinase. Immunity. (2009) 31:587-97. doi: 10.1016/j.immuni.2009.07.009

41. Gomez-Rodriguez J, Wohlfert EA, Handon R, Meylan F, Wu JZ, Anderson $\mathrm{SM}$, et al. Itk-mediated integration of $\mathrm{T}$ cell receptor and cytokine signaling regulates the balance between Th17 and regulatory T cells. J Exp Med. (2014) 211:529-43. doi: 10.1084/jem.20131459

42. Kannan AK, Kim DG, August A, Bynoe MS. Itk signals promote neuroinflammation by regulating $\mathrm{CD}^{+}$T-cell activation and 
trafficking. J Neurosci. (2015) 35:221-33. doi: 10.1523/JNEUROSCI.195714.2015

43. Huang W, Solouki S, Koylass N, Zheng SG, August A. ITK signalling via the Ras/IRF4 pathway regulates the development and function of Tr1 cells. Nat Commun. (2017) 8:15871. doi: 10.1038/ncomms15871

44. Kannan AK, Mohinta S, Huang W, Huang L, Koylass N, Appleton JA, et al. T-Bet independent development of IFNgamma secreting natural T helper 1 cell population in the absence of Itk. Sci Rep. (2017) 7:45935. doi: $10.1038 /$ srep 45935

45. Czar MJ, Debnath J, Schaeffer EM, Lewis CM, Schwartzberg PL. Biochemical and genetic analyses of the Tec kinases Itk and Rlk/Txk. Biochem Soc Trans. (2001) 29:863-7. doi: 10.1042/bst0290863

46. Yin CC, Cho OH, Sylvia KE, Narayan K, Prince AL, Evans JW, et al. The Tec kinase ITK regulates thymic expansion, emigration, and maturation of gammadelta NKT cells. J Immunol. (2013) 190:2659-69. doi: 10.4049/jimmunol.1202531

47. Felices M, Yin C, Kosaka Y, Kang J, Berg L. Tec kinase Itk in gammadelta T cells is pivotal for controlling IgE production in vivo. Proc Natl Acad Sci USA. (2009) 106:8308-13. doi: 10.1073/pnas.0808459106

48. Qi Q, Xia M, Hu J, Hicks E, Iyer A, Xiong N, et al. Enhanced development of $\mathrm{CD}^{+}$gammadelta $\mathrm{T}$ cells in the absence of Itk results in elevated IgE production. Blood. (2009) 114:564-71. doi: 10.1182/blood-2008-12-196345

49. Xia M, Qi Q, Jin Y, Wiest DL, August A, Xiong N. Differential roles of IL2-inducible T cell kinase-mediated TCR signals in tissue-specific localization and maintenance of skin intraepithelial T cells. J Immunol. (2010) 184:680714. doi: $10.4049 /$ jimmunol.1000453

50. Lee SH, Chang HS, Jang AS, Park SW, Park JS, Uh ST, et al. The association of a single-nucleotide polymorphism of the IL-2 inducible T-cell Kinase gene with asthma. Ann Hum Genet. (2011) 75:359-69. doi: $10.1111 /$ j.1469-1809.2010.00637.x

51. Ferrara TJ, Mueller C, Sahu N, Ben-Jebria A, August A. Reduced airway hyperresponsiveness and tracheal responses during allergic asthma in mice lacking tyrosine kinase inducible T-cell kinase. J Allergy Clin Immunol. (2006) 117:780-6. doi: 10.1016/j.jaci.2005.12.1330

52. Alpay F, Zare Y, Kamalludin MH, Huang X, Shi X, Shook GE, et al. Genomewide association study of susceptibility to infection by Mycobacterium avium subspecies paratuberculosis in Holstein cattle. PLoS ONE. (2014) 9:e111704. doi: 10.1371/journal.pone.0111704

53. Kim MJ, Wainwright HC, Locketz M, Bekker LG, Walther GB, Dittrich $\mathrm{C}$, et al. Caseation of human tuberculosis granulomas correlates with elevated host lipid metabolism. EMBO Mol Med. (2010) 2:258-74. doi: 10.1002/emmm.201000079

54. Seimon TA, Kim MJ, Blumenthal A, Koo J, Ehrt S, Wainwright H, et al. Induction of ER stress in macrophages of tuberculosis granulomas. PLOS ONE. (2010) 5:e12772. doi: 10.1371/journal.pone.0012772

55. Ritchie ME, Phipson B, Wu D, Hu Y, Law CW, Shi W, et al. limma powers differential expression analyses for RNA-sequencing and microarray studies. Nucleic Acids Res. (2015) 43:e47. doi: 10.1093/nar/gkv007

56. Luo W, Friedman MS, Shedden K, Hankenson KD, Woolf PJ. GAGE: generally applicable gene set enrichment for pathway analysis. BMC Bioinformatics. (2009) 10:161. doi: 10.1186/1471-2105-10-161

57. Subramanian A, Tamayo P, Mootha VK, Mukherjee S, Ebert BL, Gillette MA, et al. Gene set enrichment analysis: a knowledge-based approach for interpreting genome-wide expression profiles. Proc Natl Acad Sci USA. (2005) 102:15545-50. doi: 10.1073/pnas.0506580102

58. Luo W, Brouwer C. Pathview: an R/Bioconductor package for pathwaybased data integration and visualization. Bioinformatics. (2013) 29:1830-1. doi: 10.1093/bioinformatics/btt285

59. Carroll P, Schreuder LJ, Muwanguzi-Karugaba J, Wiles S, Robertson BD, Ripoll J, et al. Sensitive detection of gene expression in mycobacteria under replicating and non-replicating conditions using optimized far-red reporters. PLoS ONE. (2010) 5:e9823. doi: 10.1371/journal.pone.0009823

60. Reece JJ, Siracusa MC, Southard TL, Brayton CF, Urban JF Jr, Scott AL. Hookworm-induced persistent changes to the immunological environment of the lung. Infect Immun. (2008) 76:3511-24. doi: 10.1128/IAI. 00192-08

61. Chackerian AA, Alt JM, Perera TV, Dascher CC, Behar SM. Dissemination of Mycobacterium tuberculosis is influenced by host factors and precedes the initiation of T-cell immunity. Infect Immun. (2002) 70:4501-9. doi: 10.1128/IAI.70.8.4501-4509.2002

62. Feng CG, Kaviratne M, Rothfuchs AG, Cheever A, Hieny S, Young $\mathrm{HA}$, et al. NK cell-derived IFN-gamma differentially regulates innate resistance and neutrophil response in $\mathrm{T}$ cell-deficient hosts infected with Mycobacterium tuberculosis. J Immunol. (2006) 177:7086-93. doi: 10.4049/jimmunol.177.10.7086

63. Srivastava S, Ernst JD, Desvignes L. Beyond macrophages: the diversity of mononuclear cells in tuberculosis. Immunol Rev. (2014) 262:179-92. doi: 10.1111/imr.12217

64. Huang L, Nazarova EV, Tan S, Liu Y, Russell DG. Growth of Mycobacterium tuberculosis in vivo segregates with host macrophage metabolism and ontogeny. J Exp Med. (2018) 215:1135-52. doi: 10.1084/jem.201 72020

65. Mishra BB, Lovewell RR, Olive AJ, Zhang G, Wang W, Eugenin E, et al. Nitric oxide prevents a pathogen-permissive granulocytic inflammation during tuberculosis. Nat Microbiol. (2017) 2:17072. doi: 10.1038/nmicrobiol.2017.72

66. Dallenga T, Repnik U, Corleis B, Eich J, Reimer R, Griffiths GW, et al $M$. tuberculosis-induced necrosis of infected neutrophils promotes bacterial growth following phagocytosis by macrophages. Cell Host Microbe. (2017) 22:519-30.e3. doi: 10.1016/j.chom.2017.09.003

67. Gopal R, Monin L, Slight S, Uche U, Blanchard E, Fallert Junecko $\mathrm{BA}$, et al. Unexpected role for IL-17 in protective immunity against hypervirulent Mycobacterium tuberculosis HN878 infection. PLoS Pathog. (2014) 10:e1004099. doi: 10.1371/journal.ppat.1004099

68. Lockhart E, Green AM, Flynn JL. IL-17 production is dominated by gammadelta $\mathrm{T}$ cells rather than $\mathrm{CD} 4 \mathrm{~T}$ cells during Mycobacterium tuberculosis infection. J Immunol. (2006) 177:4662-9. doi: 10.4049/jimmunol.177.7.4662

69. Horvath CN, Shaler CR, Jeyanathan M, Zganiacz A, Xing Z. Mechanisms of delayed anti-tuberculosis protection in the lung of parenteral BCG-vaccinated hosts: a critical role of airway luminal T cells. Mucosal Immunol. (2012) 5:420-31. doi: 10.1038/mi.2012.19

70. Segueni N, Tritto E, Bourigault ML, Rose S, Erard F, Le Bert M, et al. Controlled Mycobacterium tuberculosis infection in mice under treatment with anti-IL-17A or IL-17F antibodies, in contrast to TNFalpha neutralization. Sci Rep. (2016) 6:36923. doi: 10.1038/srep36923

71. Segueni N, Benmerzoug S, Rose S, Gauthier A, Bourigault ML, Reverchon $F$, et al. Innate myeloid cell TNFR1 mediates first line defence against primary Mycobacterium tuberculosis infection. Sci Rep. (2016) 6:22454. doi: $10.1038 /$ srep22454

72. Benmerzoug S, Bounab B, Rose S, Gosset D, Biet F, Cochard T, et al. Sterile lung inflammation induced by silica exacerbates Mycobacterium tuberculosis infection via STING-dependent type 2 immunity. Cell Rep. (2019) 27:264964.e5. doi: 10.1016/i.celrep.2019.04.110

73. Samstein M, Schreiber HA, Leiner IM, Susac B, Glickman MS, Pamer EG. Essential yet limited role for CCR2(+) inflammatory monocytes during Mycobacterium tuberculosis-specific T cell priming. Elife. (2013) 2:e01086. doi: 10.7554/eLife.01086.013

74. Antonelli LR, Gigliotti Rothfuchs A, Goncalves R, Roffe E, Cheever AW, Bafica A, et al. Intranasal Poly-IC treatment exacerbates tuberculosis in mice through the pulmonary recruitment of a pathogen-permissive monocyte/macrophage population. J Clin Invest. (2010) 120:1674-82. doi: 10.1172/JCI40817

75. La Manna MP, Orlando V, Dieli F, Di Carlo P, Cascio A, Cuzzi G, et al. Quantitative and qualitative profiles of circulating monocytes may help identifying tuberculosis infection and disease stages. PLoS ONE. (2017) 12:e0171358. doi: 10.1371/journal.pone.0171358

76. Cohen SB, Gern BH, Delahaye JL, Adams KN, Plumlee CR, Winkler JK, et al. Alveolar macrophages provide an early Mycobacterium tuberculosis niche and initiate dissemination. Cell Host Microbe. (2018) 24:439-46.e4. doi: 10.1016/j.chom.2018.08.001

77. Huang W, Morales JL, Gazivoda VP, August A. Nonreceptor tyrosine kinases ITK and BTK negatively regulate mast cell proinflammatory responses to lipopolysaccharide. J Allergy Clin Immunol. (2016) 137:1197-205. doi: 10.1016/j.jaci.2015.08.056

78. Iyer AS, Morales JL, Huang W, Ojo F, Ning G, Wills E, et al. Absence of Tec family kinases interleukin-2 inducible T cell kinase (Itk) and Bruton's tyrosine 
kinase (Btk) severely impairs Fc epsilonRI-dependent mast cell responses. $J$ Biol Chem. (2011) 286:9503-13. doi: 10.1074/jbc.M110.165613

79. Esin S, Shigematsu M, Nagai S, Eklund A, Wigzell H, Grunewald J. Different percentages of peripheral blood gamma delta $+\mathrm{T}$ cells in healthy individuals from different areas of the world. Scand J Immunol. (1996) 43:593-6. doi: 10.1046/j.1365-3083.1996.d01-79.x

80. Huang W, Jeong AR, Kannan AK, Huang L, August A. IL-2-inducible T cell kinase tunes $\mathrm{T}$ regulatory cell development and is required for suppressive function. J Immunol. (2014) 193:2267-72. doi: 10.4049/jimmunol.1400968

81. Sagiv-Barfi I, Kohrt HE, Czerwinski DK, Ng PP, Chang BY, Levy R. Therapeutic antitumor immunity by checkpoint blockade is enhanced by ibrutinib, an inhibitor of both BTK and ITK. Proc Natl Acad Sci USA. (2015) 112:E966-72. doi: 10.1073/pnas.1500712112
Conflict of Interest: AA receives research support from 3M Corporation.

The remaining authors declare that the research was conducted in the absence of any commercial or financial relationships that could be construed as a potential conflict of interest.

Copyright (๑ 2020 Huang, Ye, McGee, Nidetz, Elmore, Limper, Southard, Russell, August and Huang. This is an open-access article distributed under the terms of the Creative Commons Attribution License (CC BY). The use, distribution or reproduction in other forums is permitted, provided the original author(s) and the copyright owner(s) are credited and that the original publication in this journal is cited, in accordance with accepted academic practice. No use, distribution or reproduction is permitted which does not comply with these terms. 